JIIP: Jurnal IImiah Ilmu Pemerintahan

Volume 5, Nomor 2, Tahun 2020

DOI: 10.14710/jiip.v5i2.8781

\title{
Pandemi ke Infodemi: Polarisasi Politik dalam Wacana Covid-19 Pengguna Twitter
}

\author{
Rachmad Gustomy \\ Program Studi Ilmu Pemerintahan, Universitas Brawijaya
}

Dikirimkan: 26 Agustus 2020 Direvisi: 17 September 2020 Diterbitkan: 30 September 2020

\begin{abstract}
INTISARI
Artikel ini ingin melacak dampak polarisasi politik pasca pemilu yang cukup kuat dalam wacana Covid-19. Pentingnya melacak perbincangan tentang Covid-19 adalah untuk melihat dampak distraksi kebijakan pemerintah dalam penanganan Covid-19. Penelitian ini menggunakan social network analisis dan social network actor dalam perbicangan di media sosial Twitter. Dengan mengidentifikasi trending topic yang terkait selama 4 bulan, maka dilakukan crawling data dengan pemograman Phyton, kemudian dilakukan analisis kumulatif teks melalui library phyton sastrawi dan visualisasi analisis SNA dengan Gephi. Temuan penelitian ini memetakan setidaknya ada dua kutub kluster besar yang berseberangan, pertama adalah kutub kluster populis pluralis dan kutub kluster populis islam. Temuannya menunjukkan bahwa wacana kebijakan Covid-19 justru menjadi ajang bagi perang sentimen masing-masing kubu, yang ternyata didominasi oleh buzzer dan sebagian kecil influencer. Sebaliknya, suara kelompok kritis dan rasional malah tenggelam oleh gaung dari para buzzer yang cenderung memiliki sentimen negatif.
\end{abstract}

\section{KATA KUNCI}

Covid-19; polarisasi; social network actor; social network analysis; teks analisis

\section{Pendahuluan}

pidemi coronavirus Covid-19 berawal dari Wuhan pada Desember 2019, dalam beberapa bulan wabah kemudian dinyatakan oleh WHO sebagai pandemi global. Sampai Agustus 2020, dari data WHO tercatat 25 juta lebih kasus dengan 848 ribu meninggal, sedang di Indonesia sendiri tercatat 178 ribu kasus dengan 7 ribu kematian yang diakibatkan oleh Covid-19 (https://www.worldometers.info/coronavirus). Pada saat inilah, wabah virus ini sudah menjadi bencana global yang memiliki pengaruh yang sangat besar, bukan hanya perubahan relasi antar manusia namun juga antar-negara.

Dalam beberapa minggu saja, setelah munculnya coronavirus Covid-19 di Cina, desasdesus menyesatkan dan teori konspirasi tentang asal-usul virus beredar di dunia yang dirangkai dengan ketakutan, "nyinyiran", kutukan dan rasisme yang disertai pemborongan masker secara masal. Hal ini karena karakter khas dari krisis masyarakat dunia maya, yang mengkaitkan antara virologi dan viralitas: tidak hanya virus itu sendiri menyebar sangat cepat,

\footnotetext{
Korespodensi:

Program Studi Ilmu Pemerintahan, Jl. Veteran Malang, Ketawanggede, Kec. Lowokwaru, Kota Malang, Jawa Timur 65145 .

Email: gustomy@ub.ac.id
} 
tetapi juga informasi dan (miss-)informasi tentang wabah ini, dan memicu kepanikan yang diciptakannya di antara masyarakat.

Hal ini tentu berbeda dengan seratus tahun lalu Ketika pandemi influenza pada 1918 yang menulari sepertiga populasi dunia dan mengakibatkan 50 juta kematian (Merchant \& Lurie, 2020). Meskipun pengobatan medis dan penanggulangan masih sangat terbatas, dan pertukaran informasi juga terbatas melalui telegram, telepon, surat, atau interaksi orang-keorang. Namun saat ini, ketika banyak instrumen berbagi informasi melalui berbagai platform media sosial yang memiliki kecepatan, jangkauan, dan penetrasi yang luar biasa (Kulkarni, Prabhu, \& Ramraj, 2020). Persoalan saat ini yang dihadapi bukan hanya masalah pandemi saja, namun juga penularan informasi palsu secara global.

Internet, melalui media social dan platform komunikasi lainnya, memiliki dua sisi tajam yang berbeda. Di satu sisi media sosial adalah alat yang efektif dan cepat dalam menyampaikan pedoman resmi dan praktik pencegahan wabah yang direkomendasikan, serta untuk menghubungkan masyarakat satu sama lain dan mendukung yang paling rentan di masyarakat. Namun disisi yang lain, juga menjadi instrumen yang paling berbahaya dalam menyebarkan informasi palsu dan teori konspirasi yang dibalut dengan kebencian dan propaganda. Dalam hal ini lockdown dan karantina tidak bisa menghentikan penyebaran informasi palsu dan ketakutan di media social atau platform populer lainnya.

Dalam skala global, kepanikan media sosial berjalan lebih cepat daripada penyebaran Covid-19 sendiri, yang mengarah ke ketidakpercayaan yang luas dan ledakan rasisme. Direktur Jenderal WHO, Tedros Adhanom Ghebreyesus, menegaskan bahwa salah satu yang harus diatasi selain epidemi coronavirus Covid-19 adalah "infodemik". Organisasi Kesehatan Dunia (WHO) mendefinisikan infodemi sebagai "An overabundance of information - some accurate and some not - that makes it hard for people to find trustworthy sources and reliable guidance when they need it." Wabah Informasi ini adalah respon yang tidak tepat dan meningkatnya kebingungan publik tentang siapa dan sumber informasi apa yang dipercaya. Tedros menyebut ini pertarungan melawan "teori troll dan konspirasi" menyebut informasi yang salah menyebabkan kebingungan dan menyebarkan ketakutan, sehingga menghambat respon terhadap wabah. Di belahan Eropa, penduduk berpenampilan Cina yang tidak pernah menginjakkan kaki di Tiongkok adalah salah satu korban pertama rasisme virus tersebut. Infodemi ini menimbulkan ketakutan dan kepanikan karena rumor yang tidak terverifikasi dan klaim berlebihan; dan mempromosikan bentuk-bentuk vigilantisme, xenophobia dan rasisme. Dalam konteks kasus Covid-19, bencana ini menjadi semakin membesar mengarah pada negatifitas perilaku manusia, yang diperparah dengan berbagai perilaku khas netizen di dunia maya; Twitter dipenuhi dengan informasi yang salah dari influencer atau buzzer, meme satir, dan semacamnya.

Dalam konteks Indonesia, infodemi memiliki jejak sentimen yang kuat dalam polarisasi politik yang sudah muncul sejak pilkada DKI Jakarta tahun 2012. Awalnya, Jokowi yang berpasangan dengan Ahok, seorang non-muslim dan Tionghoa, maju sebagai pasangan dalam Pilkada DKI Jakarta tahun 2012. PDIP (Partai Demokrasi Indonesia Perjuangan) sebagai partai pengusung disimbolkan oleh kelompok Islam garis keras adalah partai yang dianggap tidak berpihak pada kepentingan Islam. Sentimen terhadap Jokowi, Ahok dan PDIP sebagai musuh Islam mulai dibangun sejak pilkada DKI 2012, meskipun kemudian Jokowi memenangkan pertarungan kursi Gubernur. Sentimen ini semakin menguat ketika PDIP, sebagai partai terbesar, mengusung Jokowi sebagai calon presiden pada Pilpres tahun 2014. Dalam pilpres ini, ketika Jokowi disimbolkan oleh pembencinya adalah musuh Islam, maka sejak itu rivalnya dalam pencalonan Presiden Prabowo Subianto adalah pembela Islam. 
Terlepas bahwa sebenarnya secara individual keduanya tidak bisa dilacak jejak kebencian atau pembelaan terhadap Islam, namun sentimen ini diolah semakin kuat oleh kelompok Islam revivalis. Jejak sentimen pendukung Jokowi dan Prabowo baik dari partai politik ataupun organisasi sosial memang memperlihatkan adanya ketegangan politik. Pasangan Jokowi-JK yang saat itu didukung oleh PDIP, Nasdem, PKPI dan PKB, sedangkan Prabowo-Hatta di usung oleh Partai Gerindra, PAN, PPP, PKS dan Golkar (Karim, 2019). Kekuatan sosial yang ada dibalik kelompok politik tersebut memang terlihat jelas, Jokowi mendapat dukungan dari kelompok Islam tradisionalis-moderat yang direpresentasikan dalam organisasi sosial-keagamaan terbesar Nahdlatul Ulama (NU). Secara singkat, kelompok pendukung Jokowi adalah kelompok non-muslim dan islam moderat, sedangkan penantang Jokowi adalah kelompok islam revivalis yang membawa isu penegakan syariat Islam, termasuk khilafah. Tidak menjadi aneh jika Prabowo Subianto, rival Pilpres Jokowi, mendapat dukungan dari kelompok Islam-revivalis, yangsebenarnya baru terbentuk pasca reformasi, seperti: FPI (Front Pembela Islam), eks HTI (Hizbut Tharir Indonesia), dan banyak organisasi-organisasi Islam baru seperti MIUI (Majelis Intelektual dan Ulama Muda Indonesia), Alumni 212 dan semacamnya. Dalam kampanye yang sangat sengit ini, kekalahan Prabowo Subianto sebagai simbol kelompok Islam yang selalu dikalahkan semakin menguatkan sentimen kepada Jokowi dan pendukungnya.

Polarisasi politik semakin membesar dalam kampanye Pilkada DKI Jakarta tahun 2016, ketika terjadi kasus "penistaan agama" oleh Ahok yang saat itu menjabat sebagai Gubernur DKI Jakarta. Ahok dikaitkan erat dengan Jokowi, karena Ahok adalah pasangan Wakil Gubernur Jokowi dan kemudian menjadi Gubernur menggantikan Jokowi ketika terpilih menjadi Presiden. Ahok yang non muslim dan beretnis Tionghoa, dianggap sebagai simbol yang harus dilawan oleh kelompok Islam revivalis. Sampai suatu saat Ahok dianggap menghina Islam, maka penggalangan sentimen menjadi berskala Nasional. Potongan video Ahok dalam kampanye di kepulauan Seribu yang mengatakan, “...nggak pilih saya karena dibohongi (orang) pakai Surat Al Maidah 51...", menjadi momentum untuk menggalang dukungan massa Islam untuk melakukan demonstrasi besar-besaran dalam beberapa jilid. Meskipun demonstrasi ini tidak didukung oleh organisasi Islam terbesar di Indonesia seperti NU dan Muhamadiyah, organisasi-organisasi Islam lain seperti FPI, HTI, Persis dan PUI mendukung dan melakukan mobilisasi massa. Puncak demonstrasi adalah tanggal 2 Desember (bulan ke-12) 2016, yang dikenal dengan "gerakan aksi 212" yang menuntut Ahok dipenjara. Demonstrasi ini diikuti bukan hanya warga Jakarta, namun seluruh jaringan kelompok Islam di berbagai daerah. Dengan gelombang aksi ini, maka Anies Basweda rival Ahok dalam Pilkada DKI 2017, yang menjadi simbol pembela Islam oleh kelompok revivalis, berhasil memenangkan kursi Gubernur. Dari sinilah lahir kelompok alumni 212, yang menganggap dirinya sebagai simbol perlawanan Islam yang berhasil memenjarakan dan mengalahkan Ahok dalam pilkada 2017 DKI Jakarta.

Menjelang Pilpres 2019, ketegangan dan sentimen atas nama Islam semakin menguat ketika Pemerintahan Jokowi membubarkan Hizbut Thahrir Indonesia (HTI) pada Juli 2017. HTI disimbolkan sebagai kelompok yang ingin menegakkan khilafah dan syariat Islam mendapat dukungan dari kelompok Islam garis keras lain seperti FPI, Alumni 212 dan beberapa tokoh Islam. Gagasan khilafah sendiri sebenarnya mendapat tentangan yang cukup kuat dari organisasi Islam seperti NU dan Muhamadiyah serta tokoh-tokoh Islam moderat, yang menganggap itu adalah hal baru yang diadakan dalam syariat. Dengan konteks pilpres 2019, ketika Prabowo Subianto maju lagi sebagai calon Presiden menantang incumbent Jokowi, maka pertarungan ideologi dan sentimen ini semakin memperlebar jurang polarisasi politik 
dan agama (Annas, Petranto, \& Pramayoga, 2019; Margiansyah, 2019), sehingga masingmasing kelompok cenderung menyematkan stempel negatif bagi kelompok diluarnya. Selama pilpres 2019 lalu, kita akrab dengan istilah 'cebong' simbol pendukung Jokowi, 'kampret' simbol pendukung Prabowo. Paska kemenangan Jokowi dalam Pilpres 2019, muncul lagi istilah "kadrun" yang merupakan akronim dari 'kadal gurun', yang menurut penggunanya, yang diwakili oleh pernyataan Deny Siregar adalah akronim dari 'kadal gurun' yang menyimbolkan orang-orang dungu yang ingin menjadi kearab-araban (CokroTV), yang istilah ini pun kemudian juga menjadi stigma kepada kelompok Islam revivalis dalam merespon Covid-19 di Indonesia.

Kembali ke pembahasan tentang infodemik, dalam konteks infodemi, maka Jokowi dihadapkan dengan Anies Baswedan, sedangkan Prabowo sudah tidak menjadi simbol Populis Islam karena sudah menerima posisi menjadi menteri Jokowi. Posisi dan status kedua simbol ini berhadap-hadapan, Jokowi sebagai representasi pemerintah pusat, sedangkan Anies sebagai representasi pemerintah provinsi DKI Jakarta. Akibatnya respon terhadap Covid-19 menjadi kontradiktif, persebaran informasi yang tidak tersaring dengan baik di media sosial tentang Covid-19 erat kaitannya dengan dukung-mendukung antara Jokowi dan Anies Baswedan. Pertarungan politik di tengah pandemi ini semakin kentara dengan banyaknya tagar yang mengusung isu kepemimpinan politik dan kebijakan penanganan Covid-19 sekaligus. Menurut pantauan CoMuNeLab. (2020), sepanjang bulan Januari sampai Juli, gelombang infodemi di Indonesia per harinya bisa mencapai minimal 5650 tweets dan pernah mencapai hingga 114.000 tweet per hari pada bulan Maret lalu. Dari jumlah cuitan sebanyak itu, data informasi yang dianggap reliable hanya 6.860 tweet, sedangkan yang tidak realible 2.310 tweet. Isu yang muncul dan mendominasi dalam infodemi ini beragam, seperti tentang pro kontra kebijakan lockdown, tuntutan agar Menteri Kesehatan Terawan mengundurkan diri, hingga isu yang memperdalam jurang polarisasi. Selain polarisasi politik, agama juga menjadi basis infodemi yang jalin berkelindan dengan isu politik terkini (CoMuNeLab., 2020).

Pertanyaan penting dalam penelitian ini adalah, bagaimana dampak polarisasi politik mempengaruhi wacana Covid-19 pada pengguna twitter?. Penelitian ini akan dilakukan dengan menganalisis perbincangan di twitter terkait isu covid-19 yang berhubungan dengan polarisasi politik. Penelitian ini dilakukan dengan melakukan penambangan (mining) data dari pembicaraan pengguna twitter dalam merespon covid-19 atau coronavirus yang memiliki jejak sentimen polarisasi politik dampak pemilu sebelumnya. Tidak semua kicauan di ambil dalam penelitian ini, cara kerja penambangan dilakukan dengan mengidentifikasi 20 besar tagar (\#), yang dipantau di https://trends24.in/indonesia, diambil data untuk wacana yang mengandung jejak sentimen polarisasi dampak pemilu sebelumnya. Tagar yang trending dan mengandung potensi persilangan dua diskursus itu kemudian di pantau dan direkam jejak digitalnya.

Proses penambangan data ini dilakukan 7 hari kebelakang sejak tagar (\#) yang diidentifikasi trending, sesuai dengan batasan data historical kebijakan twitter, dan juga dipantau 7 hari pasca tagar itu turun trending. Proses mining dan crawling data ini dilakukan dari tanggal 10 bulan Mei sampai tanggal 10 bulan Agustus. Proses penambangan dilakukan dengan pemograman Phyton, namun karena dibatasi dari keterbatasan hardware maka data yang diambil dibatasi maksimal 50.000 pembicaraan twitter. Jadi data yang dihadirkan adalah "data berjalan" (real time) tidak sepenuhnya "data kebelakang" (historical), karena ada keterbatasan akses dari twitter yang hanya boleh menambah 7 hari kebelakang. Jadi harus diakui bahwa penelitian ini tidak menggambarkan keseluruhan total kicauan covid-19 dan polarisasi politik. Analisis teks dilakukan dengan menggunakan stemming Library Phyton 
Sastrawi yang berbasis bahasa Indonesia untuk memecah kata menjadi kata dasarnya, yang kemudian divisualiasasi menjadi wordcloud. Proses intepretasi dan visualisasi SNA dilakukan dengan software Gephi dengan intepretasi yang disajikan secara kualitatif.

\section{Social Network Analysis: Sebuah Perangkat Analisis}

Teori jaringan aktor merupakan suatu teori yang awalnya dikembangkan oleh tiga ilmuwan, yaitu Bruno Latour, Michel Callon, dan John Law. Ketiga tokoh tersebut mengembangkan Teori jaringan aktor untuk memahami jaringan terutama dalam studi sains dan teknologi. Namun, seiring waktu teori ini mengalami pengembangan oleh berbagai ilmuwan sesuai dengan bidangnya, seperti studi organisasi, komunikasi, antropologi, budaya dan berbagai bidang lain. Hal ini menurut penuturan Latour (2013), Analysis Network Theory adalah "an alternative social theory to deal with the new puzzles uncovered after carrying out our fieldwork in science and technology" (terj. Sebuah teori sosial alternatif yang berhadapan dengan teka-teki sebagai dampak dari kerja dibidang ilmu pengetahuan dan teknologi). Teori ini berpendapat bahwa suatu aktor yang terdapat dalam suatu jaringan bukan hanya merujuk pada aktor manusia saja, melainkan terdapat juga aktor non-manusia. Kedudukan kedua aktor ini dalam suatu jaringan dianggap sama karena merupakan unsur pembentuk suatu jaringan (Cressman, 2009). Teori ini berusaha untuk menjawab bagaimana suatu jaringan bertindak secara bersama-sama sebagai suatu keseluruhan yang utuh. Susanti \& Lubis (2015) ANT atau Analysis Network Theory secara eksplisit berusaha menghubungkan unsur-unsur yang berbeda bersama-sama menuju jaringan, sehingga membentuk satu kesatuan yang tampaknya koheren.

Teori jaringan aktor merupakan suatu teori yang lebih fokus terhadap bentuk atau struktur jaringan yang tersusun dari berbagai aktor yang saling terhubung. Dalam perspektif teori ini dinilai penting untuk mengetahui dan memahami awal terbentuknya suatu jaringan oleh aktor. Sebab, awal jaringan yang terbentuk menjadi penyulut pembuatan sebuah realita. Latour (2013) menjelaskan bahwa setiap aktor mempunyai keterkaitan dengan dengan orang lain sebab setiap aktor mempunyai kehidupan sosial. Hal inilah yang menjadi suatu perantara penyebaran suatu pemahaman tentang suatu hal kepada orang lain misalnya, seorang aktor mempunyai gagasan atau pemahaman suatu permasalahan yang ia sampaikan kepada publik. Pemahaman atau gagasan ini berpotensi untuk menjadi penyulut bagi publik untuk setuju dengan gagasan atau pemahamannya. Oleh karena itu, penelusuran aktor menjadi hal penting dalam perspektif teori ini untuk mengetahui struktur jaringan yang terbentuk.Dalam penelitian teori jaringan aktor digunakan sebagai alat untuk membedah jaringan yang terbentuk dalam wacana Pancasila pasca reformasi. Hal ini dilakukan dengan tujuan untuk menelusuri aktor-aktor yang terkait dalam masalah tersebut.

Social Network Analysis (SNA) digunakan untuk mengurai jejaring aktor dan wacana pembentuknya. SNA pada dasarnya adalah studi yang memperlajari tentang hubungan antara manusia dengan memanfaatkan teori graf (Tsvetovat \& Kouznetsov, 2011). SNA melihat dan mengukur hubungan sosial dalam sebuah jejaring yang dilambangkan dengan nodes dan edges. Node adalah aktor individual yang ada dalam sebuah jejaring dan saling berhubungan dengan aktor lain yang disambungkan oleh edge/ties/links. Nodes sebagai aktor individual bisa merepresentasikan manusia, organisasi, atau entitas lainnya (Wasserman \& Faust, 1994). Sedangkan, links/edges adalah relasi sosial yang menghubungkan antar nodes. Dalam konteks twitter, nodes adalah akun (jejaring mention) baik organik ataupun bot dan tagar (jejaring hashtag). Sedangkan link adalah cuitan yang menghubungkan antar akun atau hashtag. Dalam analisisnya, digunakan bahasa pemograman Phyton dan Gephi untuk crawling dan visualsiasi 
data. Di analisis pula, degree (in-degree dan out-degree) centrality-nya untuk mengetahui aktor dan tagar yang memiliki signifikansi dalam sebuah jejaring sosial di twitter.

Dalam penelitian ini, hastag atau 'tanda pagar', yang nanti disebut "tagar" yang disimbolkan (\#) adalah identifikasi awal dalam menentukan wacana. Tagar adalah adalah label di sosial media yang dibuat untuk mempermudah pencarian informasi atau posting yang berisi tema atau isu tertentu, yang disimbolkan dengan tanda pagar (\#) dari susunan kata tanpa spasi. Dengan bertumpukannya informasi di sosial media, maka tagar sangat membantu menemukan informasi yang tepat ditengah informasi yang bertubi-tubi. Dengan menggunakan tagar maka pencari informasi dapat secara cepat menemukan informasi yang dibutuhkannya. Hampir semua media sosial menggunakan tagar seperti; Twitter, Instagram, YouTube, Google+ and Pinterest. Dari tagar bisa dipetakan karakter sentimen yang dibangun oleh pengguna twitter, dengan mengidentifikasi tagar kita bisa menemukan sumber konten di media sosial, membangun gerakan sosial, dan cara untuk membangun sebuah komunitas sosial (Mulyadi \& Fitriana, 2018).

\section{Jejak Sentimen dalam Kicauan ditengah Pandemi}

Dari keseluruhan data yang dimasukkan log mining, setelah dilakukan cleansing data yang dianggap sampah, maka terlihat jelas polarisasi wacana yang terjadi. Dalam penelitian ini ada dua kutub polarisasi yang ekstrim, yaitu; pertama kluster "Populis Plural", kelompok ini dicirikan memiliki sentimen positif terhadap Jokowi, pemerintah pusat dan Ahok, yang memiliki sentimen negatif dengan kelompok pengusung khilafah. Kedua, kluster "Populis Islam" yang dicirikan, mantan pendukung Prabowo dalam Pilpres, pendukung gerakan 212, memiliki sentimen positif terhada Anies Basweda dan pemerintah Propinsi DKI Jakarta. Kelompok ini memiliki sentimen negatif dengan Jokowi dan semua orang yang kemudian mendukung Jokowi.

Dari total Populis Plural berhasil membuat 22 tagar trending topic dengan 145.073 tweet, dan sedangkan Populis Islam trending dengan 10 tagar dengan total 63.966 tweet, ini artinya kelompok Populis Plural dua kali lipat lebih banyak membuat tagar (\#) dan lebih banyak tweet yang trending daripada kelompok Populis Islam. Lebih mendalam, dari pemetaan tagar (\#) maka akan sangat terlihat polarisasi wacana yang terjadi, untuk lebih jelasnya lihat tabel 1 berikut;

Tabel 1 : Peta Polarisasi Tagar

\begin{tabular}{|c|c|c|c|c|c|}
\hline \multicolumn{3}{|c|}{ POPULIS PLURAL } & \multicolumn{3}{|r|}{ POPULIS ISLAM } \\
\hline \multicolumn{2}{|r|}{ Sentimen } & \multirow{2}{*}{$\begin{array}{l}\text { Tagar (\#) } \\
\text { \#BanpresPeduliRakyat } \\
\text { \#DukungJokowiAtasiPandemi }\end{array}$} & \multicolumn{2}{|c|}{ Sentimen } & \multirow{2}{*}{$\begin{array}{c}\text { Tagar (\#) } \\
\text { \#AniesTopLeader }\end{array}$} \\
\hline (1) & Positif & & (2) & Positif & \\
\hline (3) & $\begin{array}{l}\text { Wacana } \\
\text { Kegagalan } \\
\text { Anies }\end{array}$ & $\begin{array}{l}\text { \#CoronaBerpestaAniesDimana } \\
\text { \#AsyikReklam4niesLupaCovid } \\
\text { \#CovidNaik4niesTurun } \\
\text { \#CoronaBukanPanggungPolitik } \\
\text { \#PSBBTransisi4niesGagal } \\
\text { \#PemdaLemahPSBBgagal } \\
\text { \#AniesGabenerPembohong }\end{array}$ & & $\begin{array}{l}\text { Wacana } \\
\text { Kegagalan } \\
\text { Jokowi }\end{array}$ & $\begin{array}{l}\text { \#PempusKerePSBBGagal } \\
\text { \#JKWMelanggarKonstitusi } \\
\text { \#ImpeachmentJokowi } \\
\text { \#PresidenSintingBerskalaBesar } \\
\text { \#JokowiSilahkanMundur } \\
\text { \#IndonesiaTerserahPakde } \\
\text { \#JKWLBPHancurkanRI } \\
\text { \#GoodbyeSandiagaUno }\end{array}$ \\
\hline (5) & $\begin{array}{l}\text { Wacana } \\
\text { Penolakan } \\
\text { Demonstrasi }\end{array}$ & $\begin{array}{l}\text { \#TolakAksiDitengahPandemi } \\
\text { \#TolakKerasDemoSaatPandemi } \\
\text { \#CovidGanasDemoDilarangKeras } \\
\text { \#WaspadaDemoTularkanCovid } \\
\text { \#LawanProvokatorPandemi }\end{array}$ & & & \#PresidenDableg \\
\hline
\end{tabular}




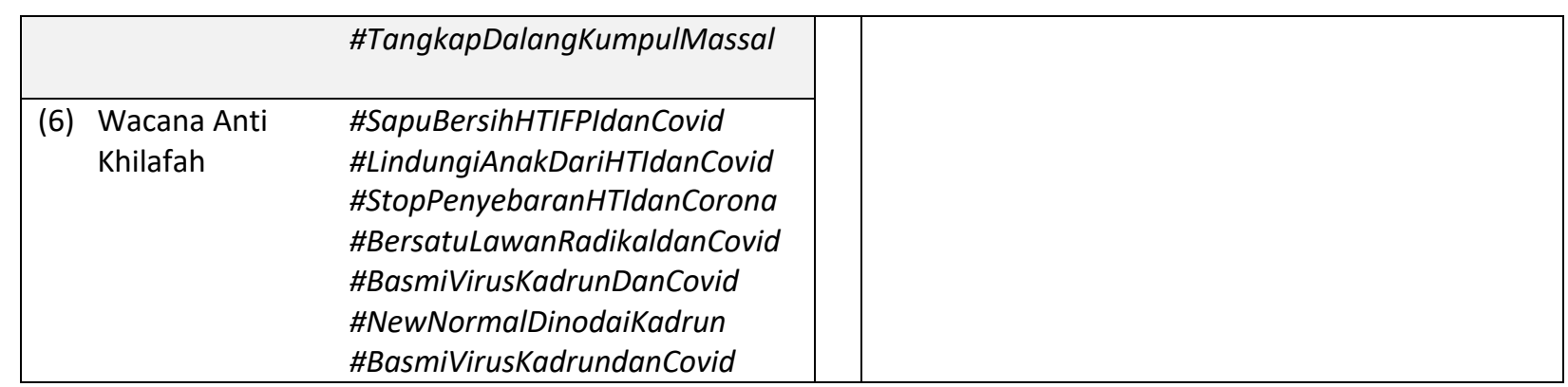

Dari pemetaan tagar yang muncul selama 4 bulan pemantauan, terlihat ada 6 kluster wacana yang berkembang, dua wacana adalah Populis Islam dan empat wacana Populis Plural. Hampir semua wacana Covid-19 yang terdampak polarisasi paska pemilu memiliki 29 tagar sentimen negatif (-), dan hanya 3 tagar yang positif $(+)$. Wacana negatif berisi ajakan untuk menolak, melawan atau mengekslusi kelompok lain, sedangkan wacana positif adalah sebuah statemen yang tidak didasari pada kebencian, namun glorifikasi terhadap keberhasilan tokoh oleh para pendukungnya di twitter. Dari pemetaan, wacana positif terlihat dalam 2 wacana; (\#1) Pertama, wacana positif dari pendukung Presiden Jokowi terhadap kinerjanya, dengan kegiatan bantuan presiden (banpres) melalui kementrian sosial dan dukungan kepada pemerintah pusat atas kinerja mengatasi pandemi Covid-19. (\#2) Kedua, wacana positif terhadap kinerja Gubernur Anies Baswedan yang dianggap pendukungnya sebagai Gubernur paling sukses dalam mengatasi pandemi covid.

Sedangkan sisanya adalah wacana negatif, diantaranya; (\#3) ketiga, wacana kegagalan Gubernur DKI Jakarta, Anies Baswedan, dalam mengatasi wabah Covid-19. Wacana ini sama populernya dengan gaung wacana (\#4) keempat, yaitu gaung kegagalan Presiden Jokowi sebagai pemerintah Pusat dalam menangani dampak pandemi Covid-19. Wacana negatif lainnya adalah serangan kepada kelompok yang dianggap selama ini menantang pemerintah pusat, dalam hal ini Presiden Jokowi, dimana wacana (\#5) kelima, adalah wacana penolakan ajakan demonstrasi, wacana ini berkembang karena muncul ajakan untuk melakukan tuntutan terhadap kinerja pemerintah dalam banyak hal. Bagi pendukung Pemerintah Pusat, alasan kondisi pandemi yang berpotensi menularkan wabah Covid-19 digaungkan untuk menggembosi penggalangan massa untuk demonstrasi. Sedangkan wacana (\#6) keenam, adalah wacana anti khilafah, yang sebenarnya adalah respon dari ajakan mendirikan khilafah dan kelompok populis Islam. Beberapa tagar tersebut memang tidak secara langsung menyerang pemerintah, namun menawarkan pendekatan khilafah dalam menangani muncul dalam tagar \#islamsolusiatasipandemi, \#newnormalislamipilihannya, \#khilafahatasipandemi, dan semacamnya. Jadi wacana tandingan kelompok islamisasi dan khilafah muncul sebagai ekspresi dukungan kepada pemerintah yang berkuasa.

Sebagaimana disebutkan diawal bahwa wacana negatif lebih dominan daripada wacana positif, pretensi negatif juga sangat mencolok terlihat ketika dilakukan analisis teks terhadap konten pembicaraannya. Analisis teks dilakukan dengan stemming sastrawi dan kemudian menghasilkan kumpulan kata dasarnya, yang selanjutnya dilakukan proses pembersihan terhadap kata-kata yang tidak memiliki atensi sentimen, seperti kata penghubung dan semacamnya. Model analisis ini memang bukan pendekatan komprehensif dalam menafsirkan sebuah wacana, namun cukup memberikan gambaran tentang karakter umum wacana yang berkembang. Model analisis teks seperti ini juga bukan dalam kepentingan menghubungkan antar konsep, namuan hanya hubungan antar kata. Meskipun sangat terbatas menafsirkan teks, namun temuan-temuan dari teks tweet masing-masing kelompok cukup menarik untuk dihadirkan. 
Kecenderungan menggunakan kata-kata tertentu terlihat berbeda dari masing-masing klaster, secara umum dapat dilihat dalam mayoritas besar kata yang digunakan kedua kelompok, perhatikan visualisasi wordcloud dibawah (lihat gambar 1 dan gambar 2). Sepuluh besar kata yang paling sering muncul dari tagar Populis Plural adalah kata; "pemerintah, covid, pancasila, khilafah, negara, corona, indonesia, anies, jakarta, jokowi". Jika diperiksa dalam konteks kalimatnya, maka kata-kata tertentu seperti; "pemerintah, covid, pancasila, negara, corona, indonesia, jokowi", sebagaian besar digunakan dalam konteks kalimat yang positif dan optimis. Sebaliknya, kata; "anies, jakarta, khilafah", lebih sering digunakan dalam konteks yang menekankan intensi negatif, pesimis dan ancaman.

Sama halnya, dari sepuluh besar kata paling sering muncul dari kluster Populis Islam, seperti; "Rakyat, tagar, ekonomi, Indonesia, Jakarta, demokrasi, normal, nasehat, radikalisme", digunakan dalam karakter serupa. Kata, "jakarta, normal, nasehat", digunakan dalam intensi positif, sedangkan kata; "rakyat, rezim, ekonomi, indonesia, demokrasi", digunakan dalam konteks negatif, pesimis dan krisis. Menariknya dua kata lainnya, "radikal" dan "penghina" dimunculkan dari Populis Islam untuk mengkritik pemerintah pusat dan bernada peyoratif. Dari analisis teks ini dapat secara sederhana disimpulkan bahwa pilihan kata dan penggunaan kata secara kumulatif digunakan secara tidak sadar untuk mendukung dan memojokkan tokoh yang diusungnya. Bagaimana penggunaan kata yang sama-sama masuk dua puluh besar, seperti kata "jokowi, anies, jakarta, khilafah", cenderung digunakan dengan sentimen yang berbeda oleh kedua kelompok.

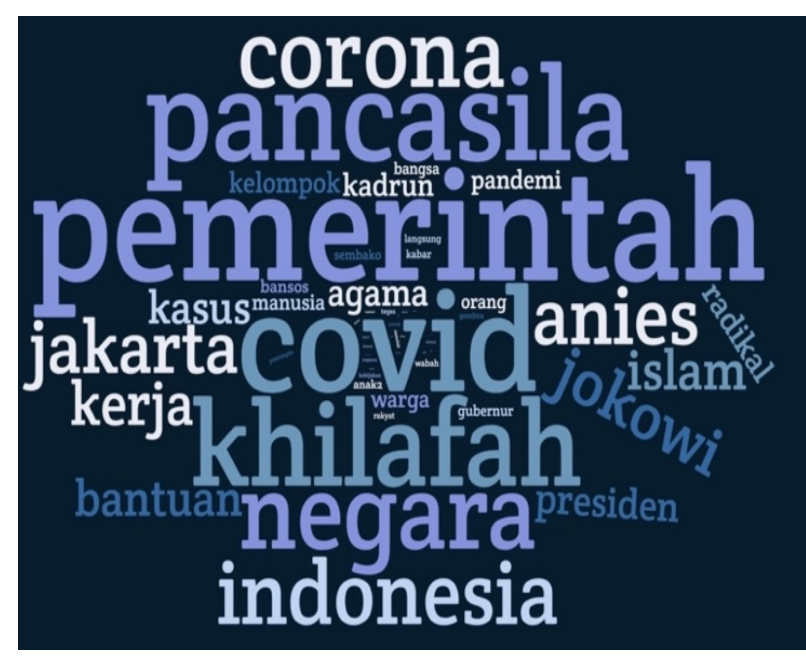

Gambar 2 : Kata Dominan Tweet Populis Plural

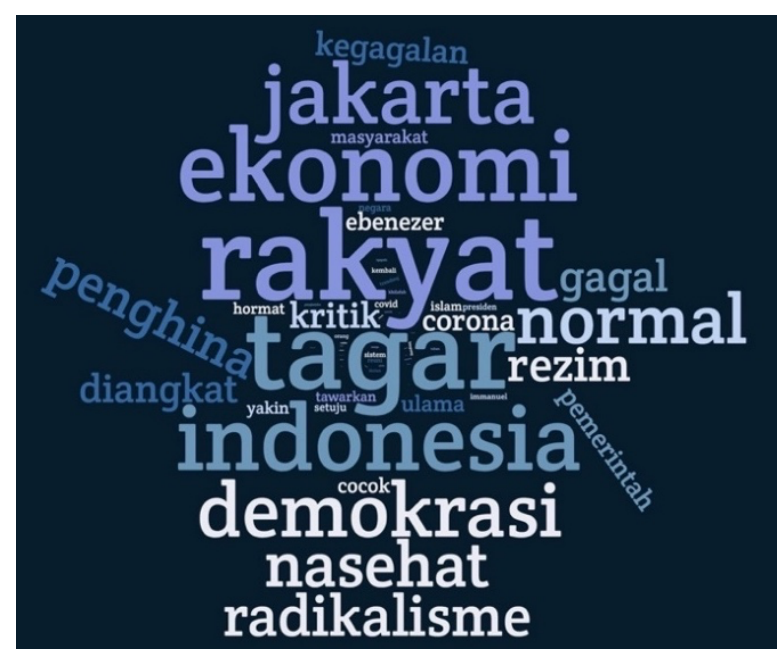

Gambar 2 : Kata Dominan Tweet Populis Islam

\section{Jejaring Wacana Kebencian dan Aktornya}

Tidak semua kicauan di twitter berasal dari manusia di dunia nyata, beberapa kicauan hanyalah robot-robot yang bertujuan untuk membuat sebuah wacana muncul ke permukaan. Dalam kacamata media dikenal istilah buzzer, yaitu kicauan yang membuat wacana semakin berdengung. Meski realitasnya ada, namun secara keilmuan belum ada definisi baku kepada karakter buzzer dan influencer, namun istilah ini sudah dikenal luas dan dipakai dalam berbagai diskusi. Dalam konteks penelitian ini, ada perbedaan mencolok yang ingin ditekankan dari identifikasi buzzer dan influencer. Akun influencer dalam penelitian ini memiliki pengertian akun yang memiliki latar belakang yang transparan, dimana bisa dilacak latar belakangnya. Akun influencer biasanya adalah milik kalangan artis, politisi, pengamat politik atau siapa saja yang memiliki jumlah pengikut yang banyak, dimana latar belakang 
follower-nya adalah orang yang memiliki preferensi dukungan terhadap isu atau pemikiran influencer. Sedangkan akun buzzer adalah akun yang tidak dapat secara jelas dipastikan siapa identitas pembuatnya, bahkan kadang hanya sebuah bot. Namun demikian akun ini akan secara aktif menyuarakan isu-isu yang dianggap penting untuk tujuan menyebar dukungan kepada follower lain. Identifikasi pembeda tidak bisa dilakukan dari motif ideologi atau ekonomi, namun dari anonimitas pemilik akun. Baik influencer maupun buzzer, tidak bisa dibedakan dari kepentingan ekonomi dan ideologi, namun dari tanggung-jawab terhadap apa yang disebarkannya. Dalam penelitian ini, proses filtering akun buzzer dicirikan dengan follower dan following yang banyak, namun akun dibuat kurang dari setahun. Ciri lain dari akun buzzer biasanya dalam waktu pendek maka akun ini akan kena sangsi, baik suspended (melanggar aturan), doesn't exist (dimatikan pembuatnya) atau protected (disembunyikan). Sedangkan akun influencer sangat mudah dicirikan akun yang dibuat lama dengan indentifikasi personal atau aktifisme yang konsisten dan natural.

Lantas bagaimana pola persebaran jejaring kebencian masing-masing kubu? Untuk mencari jawaban dari pertanyaan ini, makasemua tweet negatif disatukan, dan kemudian diidentifikasi akun-akun yang paling aktif di masing-masing kubu. Akun-akun yang paling aktif ini kemudian dilakukan verifikasi apakah termasuk influencer atau buzzer sehingga terlihat jelas bagaimana jejaring opini yang mereka bentuk. Untuk melihatnya secara visual, perhatikan gambar 3 dan 4 yang menggambarkan bagaimana jejaring aktor yang paling aktif membangun wacana. Visualisasi tersebut adalah penyatuan keseluruhan tweet yang menngandung tagar yang sudah diidentifikasi, yang selanjutnya dilakukan filtering dan cleansing. Gambar 3, adalah kluster Populis Plural, yang terdiri dari 12.206 nodes dan 68.129 edges. Sedangkan gambar 4 adalah kluster Populis Islam, dengan 15.324 nodes dan 45.232 edges. Dari gambaran singkat ini memang terlihat bahwa kluster Populis Islam lebih banyak titiknya dan lebih sedikit keterhubungan satu dengan yang lain. Dengan bahasa sederhana, kluster Populis Plural dengan jumlah tagar dan tweet yang hampir 2 kali lipat kluster Populis Islam dalam merebut trending topic, jangkauan penyebarannya lebih kecil dibanding dengan Populis Islam.

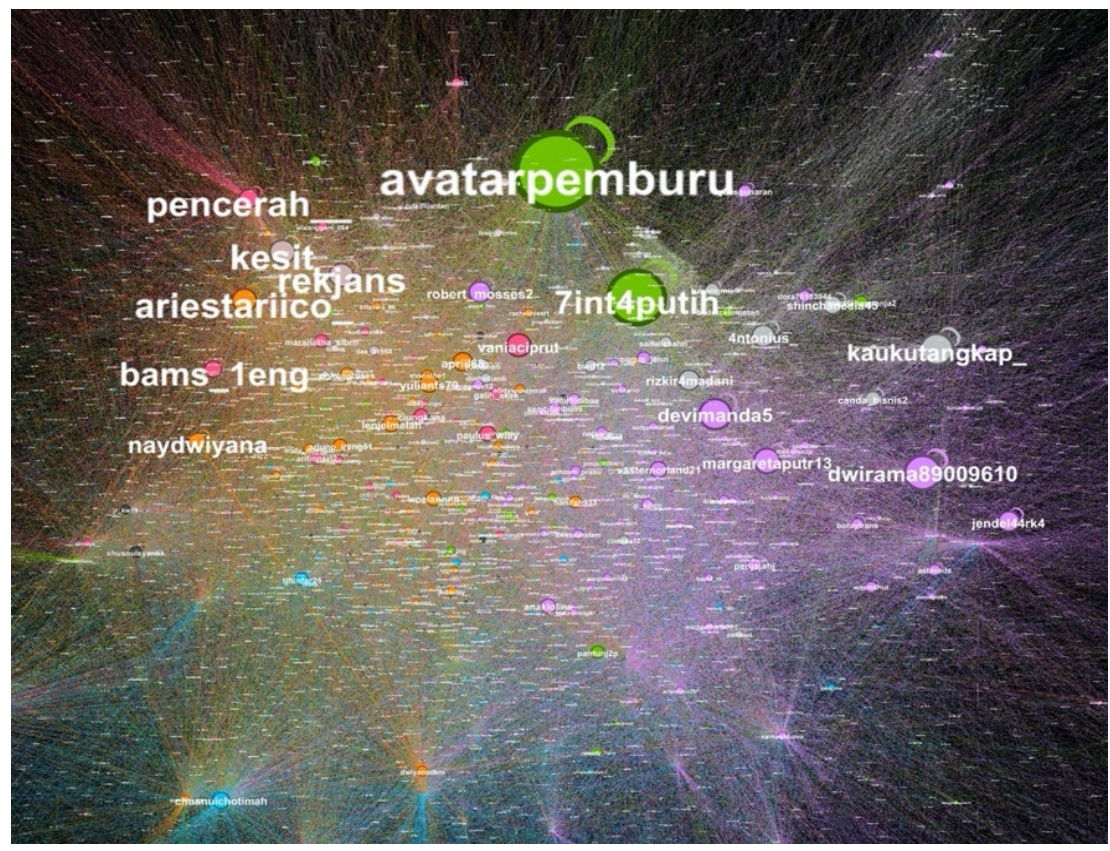

Gambar 3 : Social Negative Network Populis Plural 


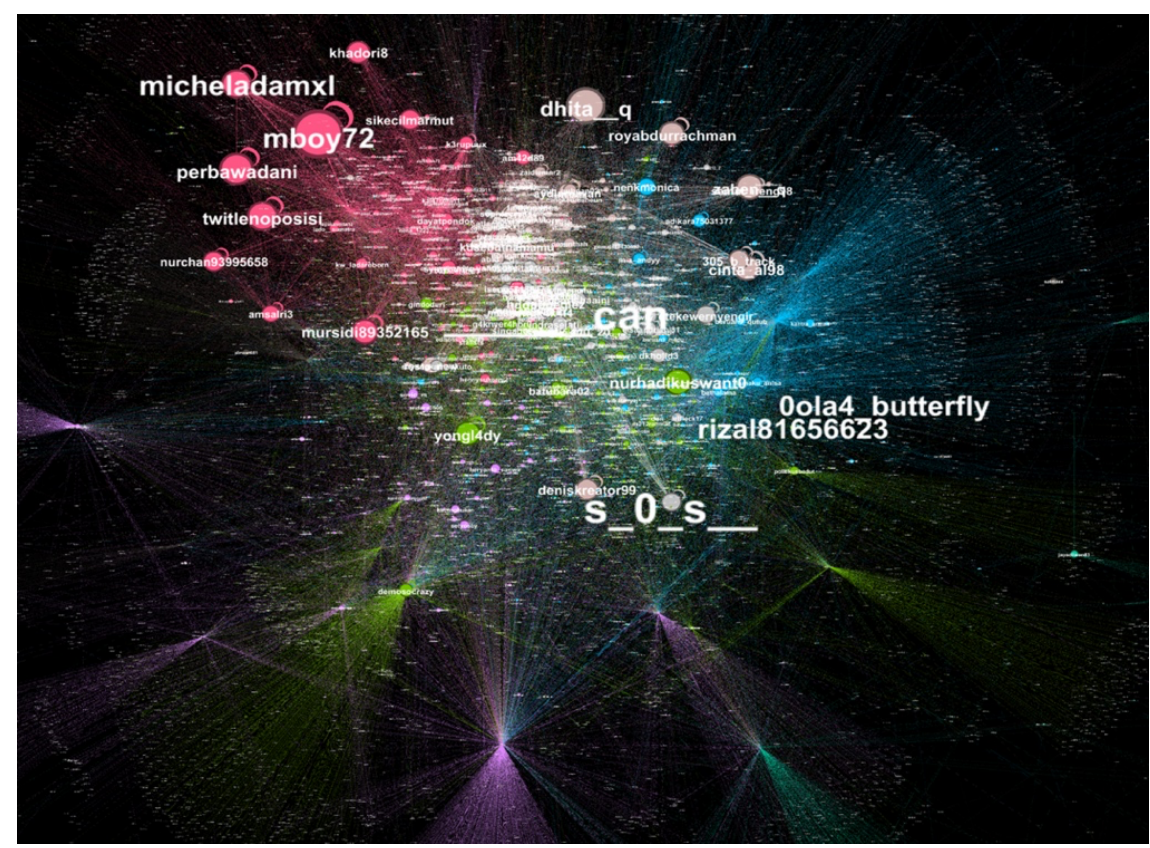

Gambar 4 : Social Negative Network Populis Islam

Lantas, apakah ini berarti bahwa kelompok Pupulis Islam lebih luas dan alami? Jika di teliti lebih jauh, dari kluster "Populis Plural", kita ambil sampel 10 akun teraktif, ternyata dipastikan bahwa 6 akun itu adalah buzzer sedangkan 4 akun lainnya adalah influencer. Akun Buzzer Populis Plural diantaranya adalah; @avatarpemburu, @7int4putih, @pencerah_. @kesit_,@lenjelmelah, @rekjans, dimana statusnya adalah "suspended" oleh kebijakan twitter. Sedangkan 4 sisanya adalah influencer, yaitu: @ariestariico_, @kaukutangkap_, @bams_1eng, @naydwiyana, yang dibuat rata-rata lebih dari 5 tahun dengan profil yang jelas. Dari jejaring "Populis Islam" dalam gambar 4 ternyata hampir semua adalah buzzer, akun @mboy72, @dhita_q, @twitlenoposisi, @micheladamxl berstatus suspended, @s_0_s_, @_can, @perbawadani berstatus “Doesn't exist", @rizal81656623, @0ola4_butterfly berstatus "baru" dibuat dan "protected", hanya satu akun @yongl4dy yang jelas influencer. Dari data ini memang jejaring "Populis Islam" lebih banyak, dengan nodes yang lebih besar, namun ada potensi kuat bahwa akun bot nya juga lebih banyak.

Dari data diatas, dapat diambil gambaran bahwa influencer, meski tetap lebih banyak buzzernya, kluster Populis Plural lebih aktif sedangkan buzzer Populis Islam meski kurang aktif jauh lebih banyak. Dari analisis ini, khususnya konteks wacana pandemi yang terpolarisasi secara politik, maka buzzer memainkan peran dalam online disinhibition effect, dimana menggambarkan melonggarnya batasan sosial dan hambatan yang biasanya hadir dalam interaksi tatap muka yang terjadi dalam interaksi di Internet. Pada level toxic disinhibition yang menurut Suler (2004), tergambar banyak perilaku berupa bahasa kasar, ancaman, atau perilaku yang mungkin tidak mereka lakukan dalam kehidupan nyata. Temuan ini menguatkan kembali toxic disinhibition menurut Suler, salah satunya adalah bentuk dissociative anonymity sebagai salah satu faktor utama di balik efek online disinhibition. Di internet, ketika buzzer berinteraksi dengan orang lain, berkomentar di forum, dan menjelajahi web sepenuhnya secara anonim. Ketika buzzer merasa anonim, dia merasa dilindungi. Dengan tetap anonim, buzzer tidak harus "memiliki" perilaku, dan dapat mengelompokkannya menjadi identitas online yang tidak terintegrasi dengan identitas offline. Anonimitas membantu buzzer merasa tidak perlu mengungkapkan diri dan terlibat dalam perilaku antisosial atau berbahaya. Selain itu invisibility dimana jenis komunikasi melalui twitter terjadi 
melalui teks. Internet menawarkan semacam perisai dan membuat buzzer tidak terlihat secara fisik. Invisibility juga membuat buzzer semena-mena mewakili siapa saja sesuai kehendaknya, dan kemudian mengadu domba tanpa merasa bersalah. Perilaku ini menyajikan kemungkinan yang tidak mungkin dicapai dalam interaksi tatap muka. Selain itu juga asynchronicity dimana sifat asinkron dari banyak bentuk komunikasi melalui internet mengarah pada disinhibisi. Percakapan twitter dan komentar tidak terjadi secara real time. Asynchronicity juga seharusnya memungkinkan pengguna twitter untuk berpikir lebih hatihati sebelum memposting, namun tumpukan informasi justru seringkali menjebak segera menyebarkan tanpa mengkonfirmasi.

\section{Jejaring Pinggiran: Wacana Positif, Kritis dan Para Free rider}

Sebagaimana dijelaskan diawal, bahwa wacana positif bukanlah paradigma dominan dalam konteks polarisasi politik. Padahal seharusnya wacana positiflah yang harus di kedepankan, karena wacana positif ini yang akan mengabarkan kebaikan dan prestasi dari masing-masing kubu. Namun faktanya, wacana positif menjadi wacana pinggiran, dari total 33 tagar hanya 3 tagar yang positif. Bagi kelompok Populis Plural wacana positif muncul dalam tagar \#BanpresPeduliRakyat dan \#DukungJokowiAtasiPandemi untuk menunjukkan prestasi dan kinerja Presiden Jokowi, dan bagi kelompok Populis Islam memunculkan \#AniesTopLeader untuk menunjukkan kinerja dan keberhasilan Anies Baswedan sebagai Gubernur DKI Jakarta. Apakah wacana positif memiliki karakter jejaring yang berbeda dengan wacana negatif? Untuk menemukan gambaran maka jejaring aktor paling berpengaruh divisualisasikan dalam gambar 6, 7 dan 8 dibawah ini.

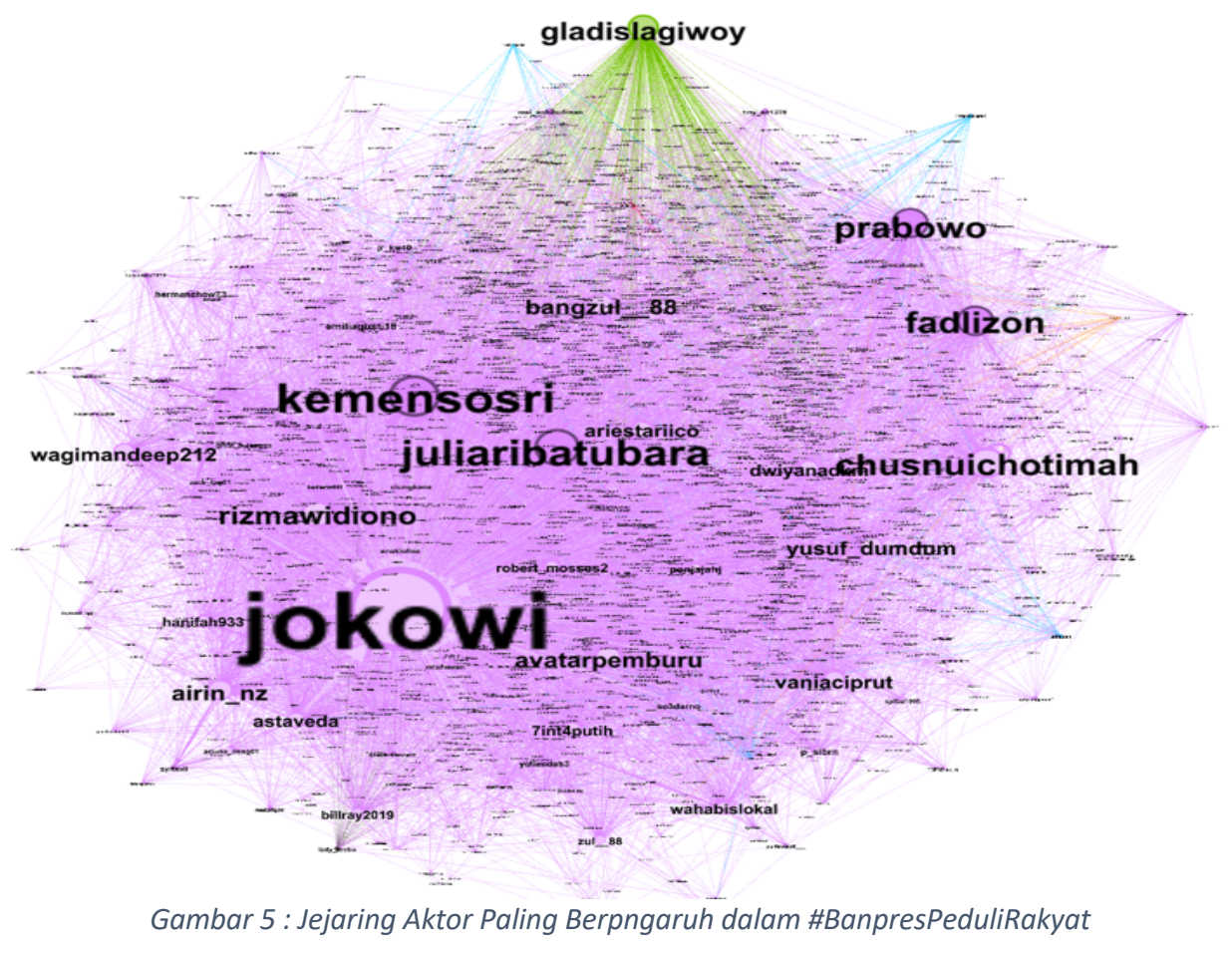




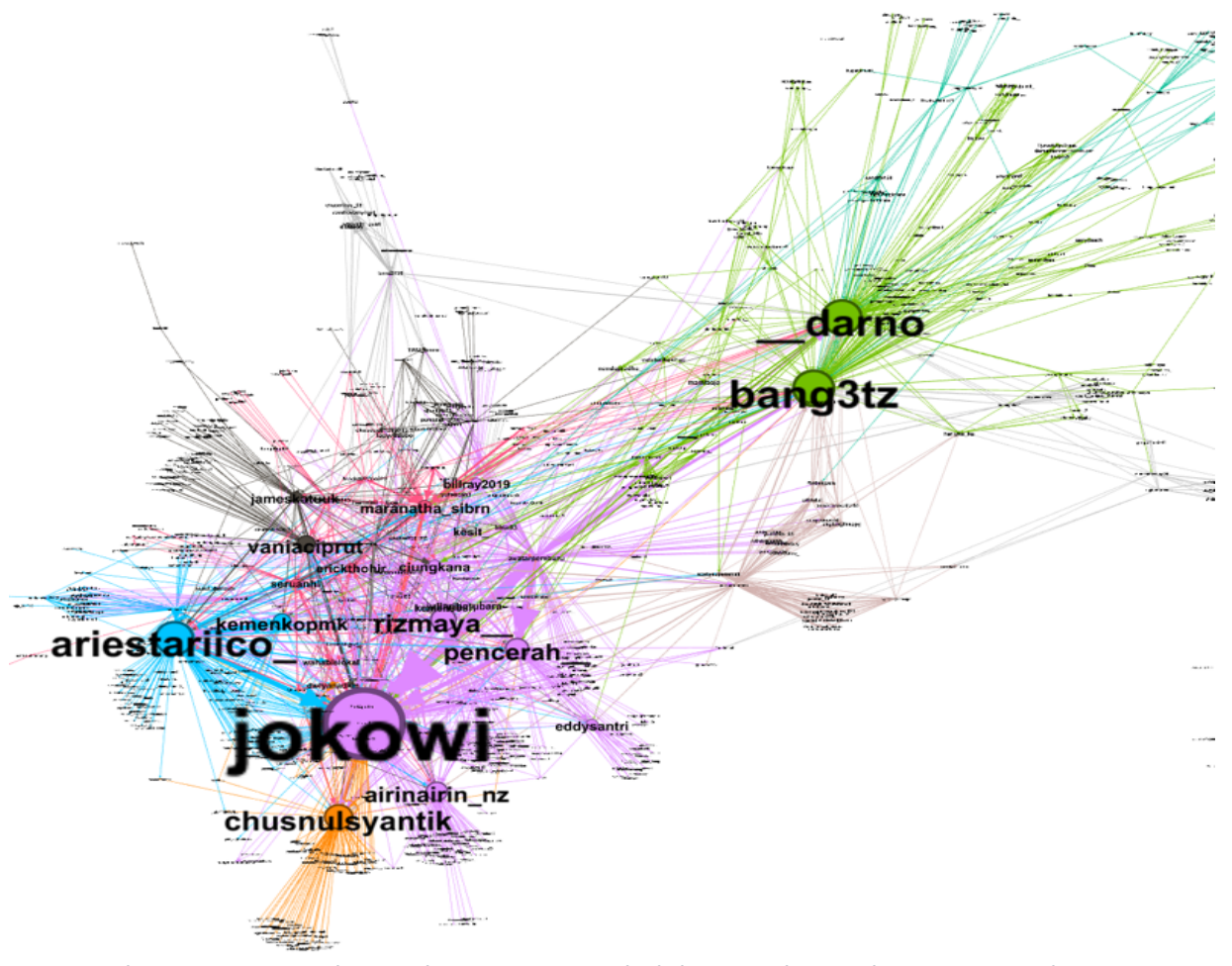

Gambar 6 : Jejaring Aktor Paling Berpengaruh dalam \#DukungJokowiAtasiPandemi

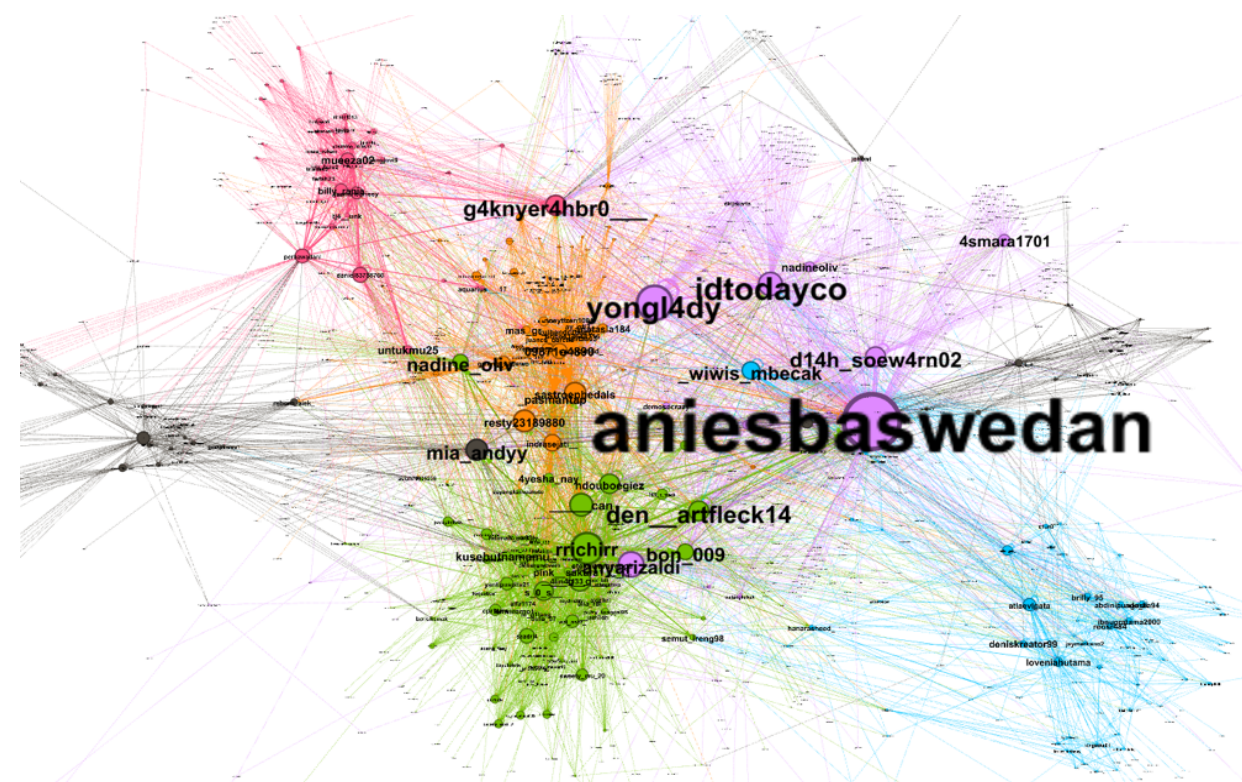

Gambar 7 : Jejaring Aktor Paling Berpnegaruh dalam \#AniesTopLeader

Dari gambar diatas, terlihat jelas bahwa sentral dalam wacana yang positif adalah aktoraktor utama yang menjadi pusat perdebatan. Dalam jejaring \#BanpresPeduliRakyat, terlihat akun @jokowi, sebagai akun resmi Presiden dan pembuat tagar, menjadi sentral utama yang kemudian banyak dipengaruhi oleh aktifitas pejabat lainnya seperti @kemensosri, @juliaribatubara dan juga @prabowo dan @fadlizon yang pernah menjadi oposan. Ini artinya bahwa hal yang positif datang dari tokoh tokoh elite di dunia nyata yang saling mempengaruhi dan digaungkan oleh influencer. Kasus yang berbeda namun memiliki karakter sama terlihat 
dari jejaring tagar \#DukungJokowiAtasiPandemi, dimana tagar ini dibuat oleh pendukung jokowi, namun kemudian disentralkan oleh tokoh yang real juga, meskipun kemudian terlihat digaungkan oleh buzzer dan influencer. (Lihat gambar 6, nodes @ariestariico, @_darno, @bang3tz, @ChusnulSyantik). Serupa namun tak sama, dari kelompok seberang tagar \#aniestopbener, yang central ada di @aniesbaswedan, akun resmi Anies Baswedan, juga digaungkan oleh influencer dan buzzer pendukungnya. Dari uraian tersebut dapat disimpulkan bahwa wacana positif sangat dipengaruhi oleh peran sentral tokoh yang menjadi pembicaraan. Selain itu juga terlihat jelas bahwa wacana positif lebih dominan disebarkan oleh influencer, sedangkan wacana negatif oleh buzzer.

Selain wacana positif, wacana pinggiran lain adalah wacana kelompok kritis yang mencoba untuk menengahi dampak polarisasi. Dalam studi kasus perang tagar antara @4niesgabenerpembohong versus @presidensintingberskalabesar, yang merupakan representasi perang dominasi wacana di twitter masing-masing pendukung. Dalam pertarungan wacana itu, muncul kelompok kritis yang sebenarnya ingin menengahi perdebatan. Menariknya, ketika polarisasi ditunjukkan dari penggunaan salah satu tagar, justru pengguna kedua tagar sekaligus dalam satu tweet menunjukkan eksistensi kelompok kritis ini (perhatikan gambar 7).

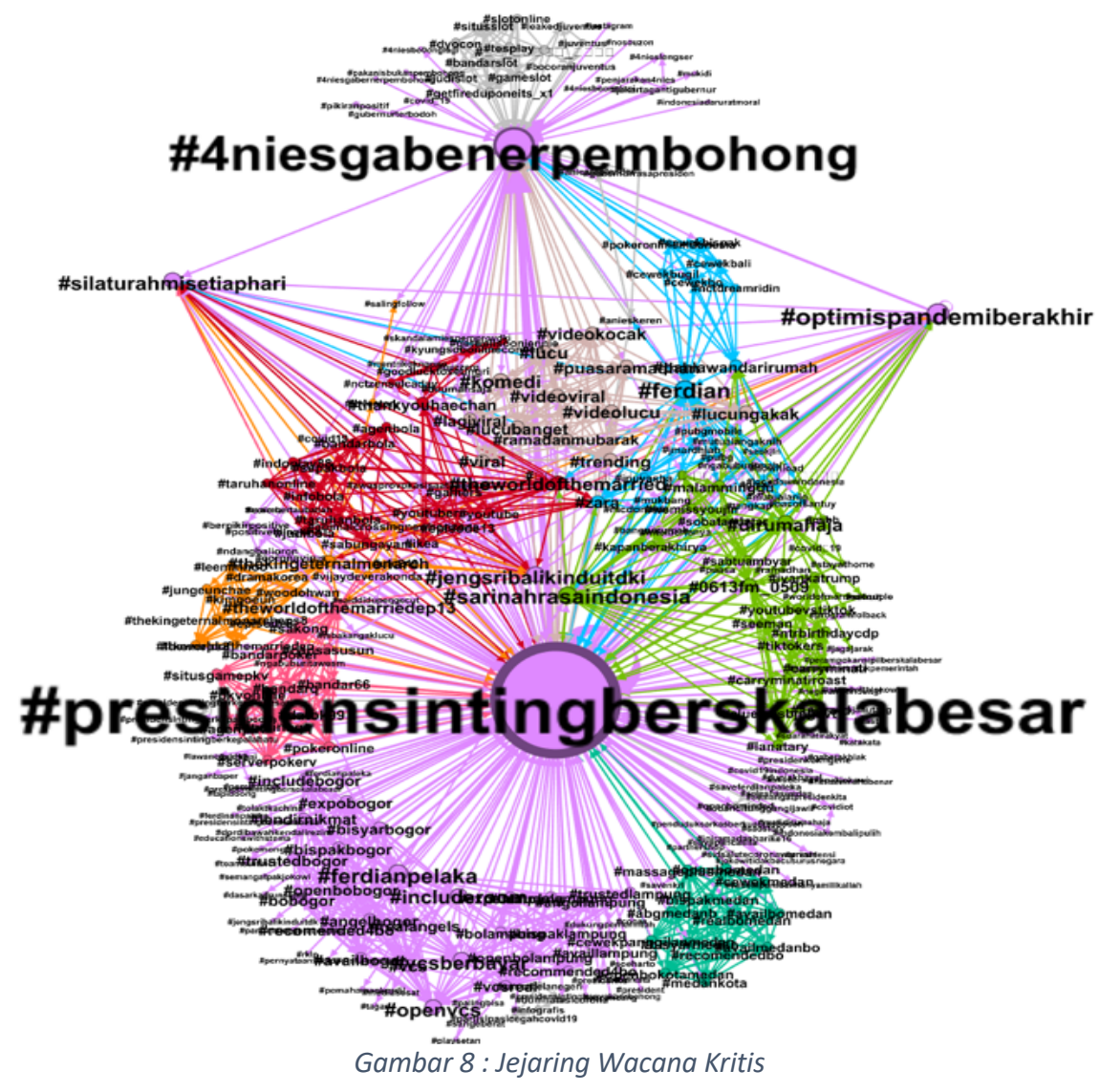

Dari sisi substansi perdebatan memang terlihat sangat tidak masuk akal, kedua kubu adalah sama-sama pemerintah, meskipun berbeda tingkat, pusat dan propinsi. Kegeraman rasionalitas inilah yang terlihat sangat mengganggu kelompok kritis dalam menyikapi perang tagar tersebut. Kelompok ini sebenarnya ingin membangun tagar kritis sebagai tandingan kedua tagar diatas, misalnya: \#Stopadudomba, \#AwasProvokasiSaatPandemi, \#silaturahmisetiaphari, \#optimispandemiberakhir, namun tidak ada tagar kritis yang menjadi 
trending topic. Jika ditelisik lebih dalam cuitan mereka, eskpresi nasihat untuk lebih rasional sangat menonjol, contohnya adalah sebagai berikut :

"Yuk cerdas dan bantuin mereka, jika salah yaa tegur dengan santun dan penuh cinta" "Dengan membuat hastag seperti ini fungsinya buat apa ? Dibaca orangnya juga engga, bikin gaduh masyarakat iya. Tolong.. ini lgi ada bencana. Bukannya doa malah mencela sana sini."

"Saling salah-salahan antara kepala daerah dan pemerintah pusat, heyy ingat masih banyak rakyat yang diluar sana lebih diutamakan, berfikirlah dewasa"

"Bingung kenapa mereka pada sibuk meyalahkan pemerintah. Apa mereka orang yg bisa diandalkan dalam mengambil keputusan bahkan untuk diri mereka sendiri? Think before typing (1)"

Namun sebagaian juga merasa sudah lelah, sehingga mengekspresikannya dalam bentuk sindiran atau nyinyiran :

"... yuk saksikan mana yg akan melambung tinggi"

"...gada habis nya ngeritik pemerintah. percuma dicaci gini gitu juga, kan kalian yg pilih.. hehe. mending ngopi"

"Para pembenci lagi berantem, dukung junjungannya"

"udah lah udah, jangan digoreng terus. Kau kira ngurus satu negara mudah"

Dunia digital ibarat gambaran dunia nyata, dimana para penumpang gelap selalu bisa hadir dalam setiap kesempatan. Dalam beberapa kasus, para buzzer sering menjadi free rider dan menumpang pada peristiwa-peristiwa populer untuk menaikkan isu yang dia bawa. Dalam visualisasi tagar yang berkaitan dan termasuk populer (lihat gambar 9 dan 10), terlihat bagaimana wacana digunakan secara arbitrer dan sewenang-wenang. Dalam tagar \#dirumahaja misalnya, ternyata juga disisipi buzzer dengan tagar \#lawanprovokatorpandemi dan satunya lagi dengan tagar \#presidensintingberskalabesar. Sama halnya dengan tagar \#Mayday2020 (termasuk 8 besar tagar yang berpengaruh) hadir juga bersamaan dari dua kubu tagar yang berbeda, yaitu \#banprespedulirakyat dan \#jkw_lbphancurkanri. Celakanya, setelah diperiksa lebih mendalam, pengguna dari kedua kubu yang menggunakan tagar \#Mayday 2020 tidak sedang memperjuangkan nasih buruh, namun sekedar basa-basi mengucapkan selamat hari buruh sambil menebar kebencian kepada kelompok lain.

Para penumpang dan penjual kebencian tidak selamanya buzzer politik, namun juga orang-orang yang yang ingin menumpang terhadap isu yang sedang trending. Dalam trending tagar yang dipakai oleh kelompok Populis Plural atau Populis Islam, selalu hadir kapitaliskapitalis recehan yang biasanya menjual produk-produk ilegal. Dalam hampir setiap tagar yang trending topik, selalu muncul tagar-tagar seperti \#bandartogel, \#bandartogelonline, \#bandartogelterpercaya, \#togelhk, \#togelonline, \#togelsd, \#togelsgp. Meski tidak jelas siapa menumpang siapa, kapitalisme dan kebencian kadang saling menumpang jika menguntungkan, (lihat gambar 9), dimana tagar \#shopeekasihneozone justru hadir bersamaan menumpang popularitas \#psbbtransisi4niesgagal. 


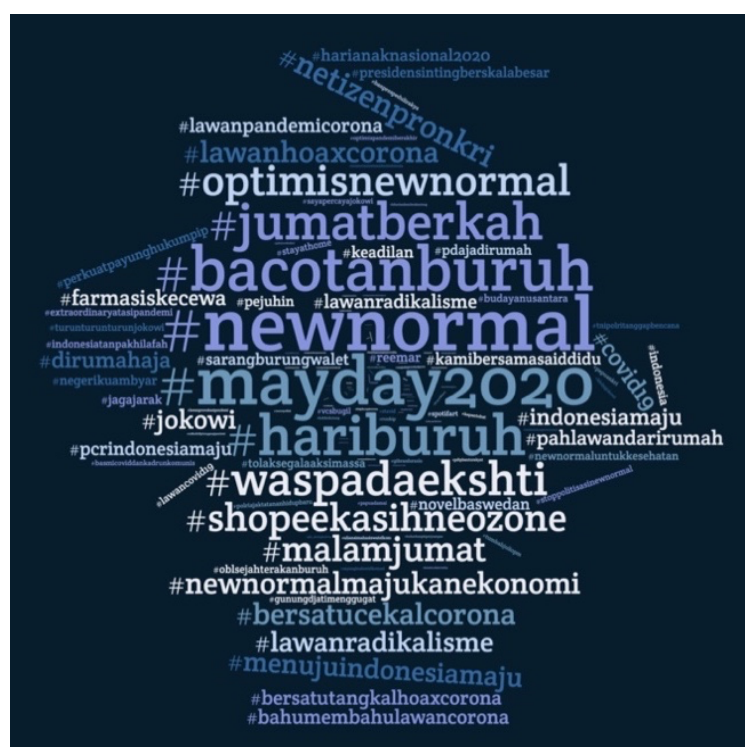

Gambar 9: Tagar Populis Plural

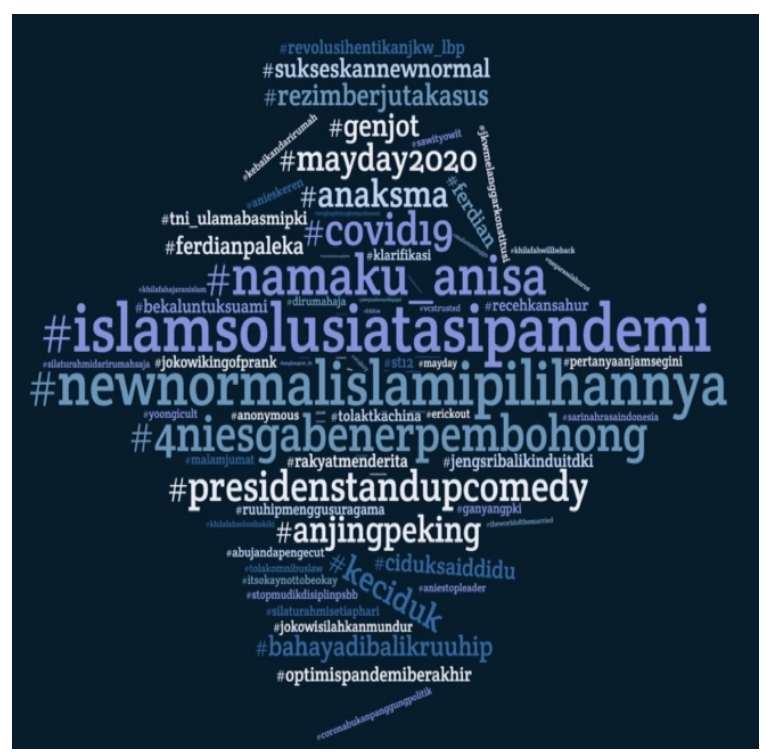

Gambar 10 : Tagar Populis Islam

\section{Penutup}

Dari penelitian ini dapat disimpulkan jika polarisasi politik masih membekas kuat sehingga mempengaruhi cara pandang mereka terhadap penanganan Covid-19. Ini artinya, perspektif dalam melihat peran pejabat pemerintah, baik pusat dan propinsi, sangat bias oleh sentimen politik. Jika polarisasi politik makin besar atau menguat, maka sangat dikhawatirkan penangan pandemi Covid-19 justru akan terdistraksi oleh sentimen negatif yang terbangun, yang pada akhirnya akan merugikan masyarakat. Disatu sisi, jejaring buzzer kedua kelompok memiliki kecenderungan untuk memperkuat sentimen negatif, daripada membuat wacana yang produktif. Faktanya, bahwa dalam kondisi terkena bencana global Covid-19, isu polarisasi politik dan agama masih menjadi komoditi dominan dari buzzer kebencian. Akan menjadi ironi jika kelompok-kelompok kebencian ini lebih dominan daripada kelompok kritis dan rasional yang berusaha mengingatkan kepentingan publik.

Pembelajaran yang bisa kita ambil adalah, di dunia maya juga bukanlah pertarungan benar dan salah, bahkan pertarungan ini juga mungkin bukan dilakukan oleh manusia. Ini bukan pertarungan setan dan malaikat, namun setan dengan setan, dan juga setan yang menumpang setan lainnya. Dalam dunia maya malaikat hanyalah sekedar menjadi jejaring pinggiran yang tidak pernah menjadi trending topik. Ini artinya dunia maya tidak selalu menjadi representasi dunia nyata, apalagi perilaku buruk dunia maya jangan samapai menulari dunia nyata. Selain itu pelajaran yang bisa kita ambil adalah kebencian ternyata menumpang apa saja, termasuk dalam informasi soal wabah dan musibah, yang sebenarnya akurasi wacana sangat menentukan keberhasilan penanganan. Akibat dari sentimen, akurasi dan kecepatan respon kebijakan publik yang sebenarnya sangat dibutuhkan semua orang, justru terdistrasksi oleh wacana-wacana sentimen yang melatarbelakanginya.

\section{Ucapan Terima Kasih}

Terimakasih kepada Abdan Syakura dan Ilham Arif Muhamad yang telah membantu proses penelitian dari crawling dan filtering data. 


\section{Pendanaan}

Penelitian untuk penulisan artikel ini dilakukan atas pembiayaan dari skema penelitian hibah internal dengan sumber dana DIPA Fakultas IImu Sosial dan IImu Politik, Universitas Brawijaya Tahun 2020.

\section{Daftar Pustaka}

Annas, F. B., Petranto, H. N., \& Pramayoga, A. A. (2019). Opini Publik dalam Polarisasi Politik di Media Sosial. Jurnal PIKOM (Penelitian Komunikasi Dan Pembangunan), 20(2), 111.

CoMuNeLab. (2020). Covid19 Infodemics Observatory.

Cressman, D. (2009). A Brief Overview of Actor-Network Theory: Punctualization, Heterogeneous Engineering \& Translation.

Karim, A. G. (2019). Mengelola Polarisasi Politik dalam Sirkulasi Kekuasaan di Indonesia: Catatan bagi Agenda Riset. Politika: Jurnal Ilmu Politik, 10(2), 215-228.

Kulkarni, P., Prabhu, S., \& Ramraj, B. (2020). COVID-19-Infodemic Overtaking Pandemic? Time to Disseminate Facts Over Fear. Indian Journal of Community Health, 32(2).

Latour, B. (2013). Reassembling the Social. An Introduction to Actor-Network-Theory. Journal of Economic Sociology, 14(2), 73-87.

Margiansyah, D. (2019). Populisme di Indonesia Kontemporer: Transformasi Persaingan Populisme dan Konsekuensinya dalam Dinamika Kontestasi Politik Menjelang Pemilu 2019. Jurnal Penelitian Politik, 16(1), 47-68.

Merchant, R. M., \& Lurie, N. (2020). Social Media and Emergency Preparedness in Response to Novel Coronavirus. Jama.

Mulyadi, U., \& Fitriana, L. (2018). Hashtag (\#) As Message Identity in Virtual Community. Jurnal The Messenger, 10(1), 44-53.

Suler, J. (2004). The Online Disinhibition Effect. Cyberpsychology \& Behavior, 7(3), 321-326.

Susanti, S., \& Lubis, A. (2015). Partisipasi Politik Perempuan pada Partai Keadilan Sejahtera Kota Medan. JPPUMA Jurnal IImu Pemerintahan Dan Sosial Politik Universitas Medan Area, 3(1), 1-13.

Tsvetovat, M., \& Kouznetsov, A. (2011). Social Network Analysis for Startups: Finding Connections on the Social Web. "O'Reilly Media, Inc."

Wasserman, S., \& Faust, K. (1994). Social Network Analysis: Methods and Applications (Vol. 8). Cambridge university press.

\section{Tentang Penulis}

Rachmad Gustomy adalah dosen prodi IImu Pemerintahan, Fakultas IImu Sosial dan Politik, Universitas Brawijaya. Penulis memiliki minat kajian dalam kebijakan publik, kajian digital pemerintahan, big data dan kajian politik islam. 